\title{
EFEKTIVITAS MENGUNYAH TEBU TERHADAP INDEKS PLAK PADA SISWA/I SD NEGERI 060937 MEDAN JOHOR
}

\author{
Rawati Siregar \\ Jurusan Keperawatan Gigi Poltekkes Kemenkes Medan
}

\begin{abstract}
Abstrak
Kebersihan gigi dan mulut adalah kondisi rongga mulut bebas dari bau mulut, tidak adanya plak dan karang gigi. Tebu merupakan jenis tumbuhan golongan rumput-rumputan yang banyak mengandung air dan serat. Jenis penelitian analitik. Metode Quasii Eksperimen (Eksperimen Semu) dengan desain Pre-Test dan Post-Test bertujuan mengetahui perbedaan indeks rata-rata sebelum dan sesudah mengunyah tebu terhadap indeks plak pada siswa/i kelas V Siswa/I SD Negeri 060937 Medan Johordengan sample 30 orang siswa. Hasil penelitian diperoleh berdasarkan perbandingan t-tabel dan t-hitung. Jika t-hitung>t-tabel maka Ho diterima.Nilai dari t-tabel dan t-hitung adalah 10,764>2,045 maka Ho ditolak yang berarti mengunyah tebu efektif dapat menurunkan indeks plak, sedangkan berdasarkan nilai probabilitas signifikan dari uji t-Test, Indeks Plak sebelum dan sesudah dilakukan pengunyahan pada tebu adalah $\mathrm{p}=0,000$, yang artinya terdapat perubahan pengukuran skor Indeks plak sebelum dan sesudah dilakukan pengunyahan pada tebu. Perbedaan yang bermakna ditunjukkan dengan nilai $(\mathrm{p}<0,05)$. Dengan indeks rata-rata sebelum mengunyah tebu 1,9 dan setelah mengunyah tebu 0,9. Indeks rata rata sebelum dan sesudah mengunyah tebu mengalami penurunan, sehingga dapat ditarik kesimpulan bahwa mengunyah tebu dapat menurunkan Indeks Plak. Diharapkan kepada siswa menjaga kebersihan gigi dan mulut dengan mengkonsumsi buah yang berserat seperti tebu untuk mengurangi plak.
\end{abstract}

Kata kunci : Mengunyah tebu, Plak

\section{PENDAHULUAN}

Kesehatan adalah baik secara fisik, mental, spiritual maupun sosial yang memungkinkan setiap orang untuk hidup secara produktif, secara sosial dan ekonomis (Undang-Undang 36 Tahun 2009). Demi kesejahteraan dan kemajuan Negara dilakukanlah pembangunan kesehatan dengan tujuan terciptanya masyarakat Indonesia yang hidup dan berperilaku dalam lingkungan sehat dan mampu menjangkau pelayanan kesehatan yang bermutu (Kementrian Kesehatan RI, 2012).

Menurut Siswanto (2010) sehat adalah suatu kondisi dimana segala sesuatu berjalan normal dan bekerja sesuai fungsinya dan sebagaimana mestinya. Kesehatan merupakan bagian terpenting dalam kehidupan manusia,baik secara jasmani maupun rohani, hal ini dapat dicapai jika tubuh kita sehat. Kesehatan yang perlu diperhatikan selain kesehatan tubuh secara umum adalah kesehatan gigi dan mulut karena kesehatan gigi dan mulut dapat mempengaruhi kesehatan tubuh secara menyeluruh.

Gigi dan mulut merupakan bagian penting yang harus dipertahankan kebersihannya, karena melalui organ mulutkuman dapat masuk. Jika ditinjau dari segi fungsinya, gigi dan mulut mempunyai peran yang besar dalam mempersiapkan makanan sebelum melalui proses pencernaan yang selanjutnya. Karena gigi dan mulut merupakan salah satu kesatuan dari anggota tubuh yang lain, kerusakan pada gigi dan mulut dapat mempengaruhi kesehatan tubuh secara langsung atau tidak langsung.

Kebersihan mulut anak secara umum lebih buruk dibanding orang dewasa karena pada umumnya anak lebih banyak makan-makanan dan minuman yang manisdan jarang membersihkannya (Machfoedz dan Zein, 2005).

Mengunyah makanan memiliki banyak manfaat yang baik bagi tubuh terutama dalam menjaga kesehatan mulut yang baik. Mengunyah makanan merupakan latihan yang bagus untuk rahang dan gigi juga membantu menjaganya agar tetap kuat dan sehat. Selain membersihkan partikel makanan dari mulut, air liur yang diproduksi saat mengunyah dengan baik juga membantu dalam membersihkan dari bakteri dalam mulut. Lebih sedikit bakteri dalam mulut memastikan bahwa berkurangnya penumpukan sisa makanan dan kerusakan gigi.

Plak gigi adalah deposit lunak tidak bermineral yang berbentuk dari campuran matriks ekstrasel, komponen anorganik, sisa makanan dan bakteri yang melekat pada permukaan gigi atau pun protesa. Plak gigi mengandung bakteri yang mampu berkoloni dengan sendirinya. Salah satu contoh bakteri tersebut adalah streptococcus mutansyang mampu memfermentasi karbohidrat menjadi asam sehingga mengakibatkan terjadinya karies gigi dan penyakit periodontal. Kedua penyakit ini dapat dicegah 
dengan cara mengontrol plak pada permukaan gigi. Salah satunya adalah dengan makan makanan yang mengandung serat.

Tebu merupakan tanaman yang sering dikonsumsi, baik dengan cara meminum air perasannya atau dengan cara mengunyah langsung batang tebu yang telah dipotong kecil-kecil. Potongan tebu mengandung serat dan cairan manis, serat yang terdapat dalam tanaman tebu mengandung selulosa, pentosan, liginin yang sangat berguna untuk kebersihan gigi dan mulut. Sifat mekanis dari serat tebu yang dikunyah dapat membantu menimbulkan efek seperti sikat yang dapat membersihkan permukaan gigi (Haida, 2014). Tebu ini juga memerlukan pengunyahan yang cukup keras sehingga dapat mendorong sekresi ludah. Sehingga buah tebu dapat membersihkan gigi dari sisa makanan secara alami.

Berdasarkan latar belakang peneliti tertarik untuk mengetahui bagaimana Efektifitas Mengunyah Tebu Terhadap Indeks Plak Pada Siswa/i Kelas VSD Negeri 060937 Medan Johor

\section{Rumusan Masalah}

Berdasarkan latar belakang maka perumusan masalah dalam penelitian adalah bagaimana Efektifitas Mengunyah Tebu Terhadap Penurunanan Debris Indeks Pada Siswa/i Kelas V SD Negeri 060937 Medan Johor

\section{Metode \\ Jenis dan Desain Penelitian}

Jenis penelitian yang digunakan adalah analitik dengan metodeQuasii Eksperimen(eksperimen semu) yaitu suatu penelitian dengan adanya suatu perlakuan terhadap kelompok sampel tetapi tidak ada kelompok kontrol (kelompok sampel mendapatkan perlakuan) dan rancangan digunakan adalah Pre-Test dan Post-Test Desain.

\section{Populasi}

Populasi dalam penelitian ini adalah seluruh siswa/i Kelas V SD Negeri 060937 Medan Johoryang berjumlah 30 orang.

\section{Sampel}

Sampel adalah sebagian yang diambil dari keseluruhan objek yang diteliti dan dianggap mewakili populasi.Dalam penelitian ini sampel yang diambil adalah siswa/i kelas V SD Negeri 060937 Medan Johoryang berjumlah 30 orang dengan teknik total sampling.

\section{Hasil Penelitian \\ Analisa Univariat}

Data yang dikumpulkan adalah hasil penelitian yang dilakukan terhadap siswa/i kelas V SD Negeri 060937 Medan JohorTahun 2018. Pengumpulan data dilakukan dengan pemeriksaan langsung ke mulut siswa/i yang menjadi sampel dari penelitian mengunyah tebu. Setelah seluruh data terkumpul, maka dibuat analisa data dengan cara membuat tabel distribusi frekuensi untuk masingmasing kelompok sampel. Kemudian dilakukan pengolahan data secara statistik dengan menggunakan tTest.
Tabel 4.1.

Distribusi Frekuensi Debris Indeks Sebelum Mengunyah Tebu Pada 30 Siswa/i Kelas VSD Negeri 060937 Medan Johor

\begin{tabular}{lcc}
\hline $\begin{array}{l}\text { Kriteria Debris } \\
\text { Indeks (DI) }\end{array}$ & $\begin{array}{c}\text { Jumlah } \\
(\mathrm{n})\end{array}$ & $\begin{array}{c}\text { Persentase } \\
(\%)\end{array}$ \\
\hline Baik & 2 & 6,7 \\
Sedang & 8 & 26,7 \\
Buruk & 20 & 66,6 \\
\hline \multicolumn{1}{c}{ Jumlah } & 30 & 100 \\
\hline
\end{tabular}

Dari tabel diatas dapat diketahui bahwa Indeks Plak siswa/i sebelum mengunyah tebu mayoritas dengan kriteria buruk yaitu sebanyak 20 orang $(66,6 \%)$.

Tabel 4.2

Distribusi Frekuensi IndeksPlak Sesudah Mengunyah Tebu Pada 30 Siswa/i Kelas V SD Negeri 060937 Medan Johor

\begin{tabular}{lcc}
\hline $\begin{array}{l}\text { Kriteria Debris Indeks } \\
\text { (DI) }\end{array}$ & $\begin{array}{c}\text { Jumlah } \\
\text { (n) }\end{array}$ & $\begin{array}{c}\text { Persentase } \\
(\%)\end{array}$ \\
\hline Baik & 8 & 26,6 \\
Sedang & 22 & 73,4 \\
Buruk & 0 & 0 \\
\hline Jumlah & 30 & 100 \\
\hline
\end{tabular}

Dari tabel diatas dapat diketahui bahwa Indeks Plak siswa/i sesudah mengunyah tebumayoritas dengan kriteria sedang sebanyak 22 orang (73,4 \%).

Tabel 4.3

Debris Indeks Rata-Rata Sebelum dan Sesudah Mengunyah Tebu Pada Siswa/i Kelas V SD Negeri 060937 Medan Johor

\begin{tabular}{cccc}
\hline $\begin{array}{c}\text { Indeks } \\
\text { Rata-Rata }\end{array}$ & $\begin{array}{c}\text { Sebelum } \\
\text { Mengunyah } \\
\text { Tebu }\end{array}$ & $\begin{array}{c}\text { Sesudah } \\
\text { Mengunyah } \\
\text { Tebu }\end{array}$ & $\begin{array}{c}\text { Penurunan } \\
\text { (Selisih } \\
\text { Indeks) }\end{array}$ \\
\hline $\begin{array}{c}\text { Indeks } \\
\text { Plak }\end{array}$ & 1,9 & 0,9 & 1 \\
\hline
\end{tabular}

Dari Tabel 4.3 dapat diketahui bahwa Indeks Plak rata-rata sebelum mengunyah tebu adalah 1,9 . Indeks Plak, setelah mengunyah tebu mengalami penurunan menjadi 0,9 .

\section{Analisa Bivariat}

Untuk menguji dua sampel yang berpasangan maka digunakan paired sample t-Test. Dimana dengan t-Test ini dapat diketahui apakah ada pengaruh mengunyah tebu efektif terhadap penurunan debris indeks. Adapun hasil tTest yang dilakukan dengan menggunakan Komputer adalah sebagai berikut : 
Tabel 4.4

Tabel Uji Paired t-Test Dependen Sebelum dan Sesudah Mengunyah Tebu Pada Siswa/i Kelas V SD Negeri 060937 Medan Johor

\begin{tabular}{ccccccc}
\hline No & $\begin{array}{c}\text { Mengunyah } \\
\text { tebu }\end{array}$ & $\begin{array}{c}\text { Mean } \\
\text { sebelum dan } \\
\text { sesudah }\end{array}$ & $\mathrm{N}$ & $\mathrm{T}$ & $\mathrm{P}$ & $95 \%$ \\
\hline 1. & $\begin{array}{c}\text { Mengunyah } \\
\text { tebu }\end{array}$ & 9,653 & 30 & 10,764 & 0,000 & $0,781-$ \\
& & & & & 1,148 \\
\hline
\end{tabular}

Berdasarkan Nilai Probabilitas

Jika probabilitas $>0,005 \longrightarrow \mathrm{H}_{0}$ diterima

Jika probabilitas $<0,005 \longrightarrow H_{0}$ ditolak

Dari tabel diatas diketahui bahwa probabilitas adalah 0,000 . Oleh karena itu probabilitas $\mathrm{p}<0,005$, maka hipotesis nol $\left(H_{0}\right)$ ditolak, yang berarti ada efektivitas mengunyah tebu terhadap penurunan debris indeks pada Siswa/i Kelas V SD Negeri 060937 Medan Johor.

\section{Pembahasan.}

Plak gigi adalah deposit lunak tidak bermineral yang berbentuk dari campuran matriks ekstrasel, komponen anorganik, sisa makanan dan bakteri yang melekat pada permukaan gigi atau pun protesa. Plak gigi mengandung bakteri yang mampu berkoloni dengan sendirinya. Salah satu contoh bakteri tersebut adalah streptococcus mutansyang mampu memfermentasi karbohidrat menjadi asam sehingga mengakibatkan terjadinya karies gigi dan penyakit periodontal. Kedua penyakit ini dapat dicegah dengan cara mengontrol plak pada permukaan gigi.

Berdasarkan pemeriksaan awal yang telah dilakukan terhadap seluruh sampel, diketahui bahwa kriteria Indeks Plak buruk sebelum mengunyah tebu sebanyak 20 siswa/i yaitu 66,6\%, kriteria Indeks Plak sedang sebanyak 8 siswa/i yaitu 26,7\% dan kriteria Indeks Plak baik sebanyak 2 siswa/i yaitu 6,7\%. Sedangkan setelah mengunyah tebu kriteria Indeks Plak buruk tidak ada, kriteria Indeks Plak sedang sebanyak 22 siswa/i 73,4\% dan kriteria Indeks Plakbaik sebanyak 8 yaitu 26,6\%. Dapat disimpulkan 30 orang siswa/i kelas V mengalami peningkatan skor Indeks Plak. Nilai signifikasi dari uji tTest, Indeks Plak sebelum dan sesudah dilakukan pengunyahan pada tebu adalah $\mathrm{p}=0,000$, yang artinya terdapat perubahan pengukuran skor Indeks Plak sebelum dan sesudah dilakukan pengunyahan pada tebu. Perbedaan yang bermakna ditunjukkan dengan nilai $(\mathrm{p}<0,05)$.

Tebu bermanfaat karena kandungan mineral yang sangat tinggi dalam air tebu dan sangat efektif untuk megatasi kerusakan gigi dan bau mulut. Mineral banyak dibutuhkan oleh gigi untuk memperkuat struktur gigi dan juga meningkatkan enzim khusus yang bisa mencegah bau mulut. Bahkan jika diminum secara teratur maka bisa meningkatkan kesehatan gigi dan membuat gigi menjadi lebih putih.

Salah satu cara untuk membersihkan debris adalah dengan mengunyah tebu, karena teksturnya yang keras sehingga saat mengunyah tebu secara fisiologis akan merangsang mulut untuk menghancurkan makanan yang ada dalam mulut sebelum masuk kedalam pencernaan sehingga dapat membersihkan mulut dari debris secara alami (Hermawati, E, 2010).

\section{Kesimpulan}

Dari hasil penelitian yang telah dilakukan oleh peneliti maka dapat disimpulkan bahwa :

1. Indeks Plak rata-rata sebelum mengunyah tebu adalah buruk $(1,9)$.

Indeks Plak rata-rata sesudah mengunyah tebu adalah sedang $(0,9)$.

2. Perbedaan Indeks rata rata sebelum dan sesudah mengunyah tebu mengalami penurunan dengan selisih indeks adalah 1.

3. Hasil t-Test Dependen diperoleh ada efektivitas mengunyah tebu terhadap penurunan Indeks Plak pada siswa/i Kelas V SD Negeri 060937 Medan $\operatorname{Johor}(\mathrm{p}=0,000)$

4. Mengunyah tebu dapat menurunkan Debris Indeks pada siswa/i V SD Negeri 060937 Medan Johor

\section{Saran}

Sesuai dengan hasil penelitian yang telah dilakukan, diharapkan:

1. Kepada siswa/i Kelas V SD Negeri 060937 Medan Johor lebih menjaga kebersihan gigi dan mulut dengan cara menyikat gigi 2 kali sehari (pagi sesudah sarapan dan malam sebelum tidur) serta memeriksakan kesehatan gigi dan mulut ke dokter gigi minimal 6 bulan sekali.

2. Kepada siswa/i KelasV SD Negeri 060937 Medan Johormengkonsumsi buah yang berserat seperti tebu untuk mengurangi debris indeks sehingga dapat mengurangi terjadinya karies.

\section{DAFTAR PUSTAKA}

Arikuto, S., 2006, Metodelogi Penelitian, Bina Aksara, Yogyakarta:Rineka Cipta.

Hardianto, L., 2012, Pendidikan Kesehatan Gigi dan Mulut, Yogyakarta:EGC.

Herijulianti, E., Indriani, T.S., Artini S., 2012,Pendidikan Kesehatan Gigi, Jakarta : EGC.

Hermawati, E., 2010, Efektivitas Mengunyah Buah Apel dan Mengunyah Buah Jambu Biji Terhadap Perubahan Angka Debris Indeks Pada Siswa Kelas VII SMP N 24 Semarang, Skripsi, Jurusan Keperawatan Gigi, Poltekkes Kemenkes Semarang.

Haida, Erida K., 2014, Perbandingan Efektivitas Mengunyah Buah Pir dan Bengkuang Terhadap Penurunan Indeks Plak, Skripsi, Fakultas Kedokteran, Universitas Lambung Mangkurat, Kalimantan Selatan.

Indriani, Hetty., 1992, Pembudidayaan Tebu di Lahan Sawah dan Tegalan, Jakarta : Penebar Swadaya.

Machfoedz, Ircham., 2005, Menjaga Kesehatan Gigi dan Mulut Anak-anak, Yogyakarta : Fitramaya.

Notoatmodjo, Soekidjo., 2008,Metodologi Penelitian Statistik, Jakarta: Rineka Cipta.

2012 Metodologi Penelitian Statistik,Jakarta:Rineka Cipta.

Nio, O, K., 1992, Daftar Analisa Bahan Makanan, UIPress, Jakarta. 
Nugroho, Cahyo., 2017, Efek Konsumsi Jajanan Tebu Batang Terhadap Kebersihan Gigi dan Mulut Pada Siwa/i Kelas $V$ SDN 3 Palimanan Timur Kecamatan Palimanan Kabupaten Cirebon, Skripsi,Jurusan Keperawatan Gigi, Poltekkes Kemenkes Tasikmalaya.

Putri, dkk., 2012, Ilmu Pencegahan Penyakit Jaringan Keras dan Jaringan Pendukung Gigi, Jakarta : EGC.

Rukmana., 2015,Untung Selangit dari Agribisnis Tebu, Yogyakarta: Lily Publisher.

Siswanto, H.,2010,Pendidikan Kesehatan Anak Usia Dini, Yogyakarta:Pustaka Rihama.

Tarigan, R., 1999, Kesehatan Gigi dan Mulut, Jakarta : EGC.
2012, Kesehatan Gigi dan Mulut, Jakarta : EGC.

http://Idafarida73.blogspot.co.id/2012/09/cara-mengukurkebersihan-mulut-ohi-s.html?m diakses Tanggal 8 Maret 2018

http://rlagista.wordpress.com/2013/12/01/ohioral-hygiene-index/\#comment-55 